B 205

\title{
ナノ粒子分散系ER流体の回転せん断流れにおける モルフォロジーとER効果*
}

中野 政身 ${ }^{\circ}$ (東北大学)

\section{Morphology and ER Effects of Nano-Particle Electrorheological} Suspension in Rotational Shear Flow Mode

\author{
Masami NAKANO
}

\begin{abstract}
In this research, the transient response of induced shear stress and the related flow behavior of an ER suspension containing nano-sized TiO2 particles dispersed in silicone oil have been investigated when it has been under the simultaneous stimulus of a constant DC or AC electric field and rotational shear using a parallel rotary disk rheometer. The effects of shearing time, electric field strength, DC or $\mathrm{AC}$, and very narrow gap height between disk electrodes on the induced shear stress are investigated in close relation to the morphology of the visualized flow patterns.

Keywords : Non-Newtonian fluid, Electrorheological fluid, Nano-particle, Flow morphology, ER effect
\end{abstract}

\section{1. 粕 言}

粒子分散系E R 流体（Electro-Rheological Fluid）は電 場下で分散微粒子が分極することにより鎖状につながり クラスターを形成することによって見掛け上粘性を可逆 的に変化させることのできる機能性流体であるり。その 電場印加による粘性の変化特性は, 印加電場強度によっ て降伏せん断応力が変化するビンガム流体に類似した举 動を示し，その電場に対する変化速度も数 $\mu \mathrm{sec}$ と速く ダンパ,バルブ，クラッチなどの多くの機械要素及び機 械システムへの応用が試みられてきている．特に，本研 究では，ER流体を用いたデバイスのマイクロ化の可能 性に着目し，ER流体を作動流体とするマイクロフルー ドパワーシステム(MFPS)の棰筑を目的に，マイクロ粒 子分散系 ER 流体の微小閒隙でのER効果や流動举娌に ついて検討してきている2).3)。

ここでは，粒子分散系 ER R流体のマイクロデバイスへ の応用を前提に, TiO2のナノ粒子を分散したER流体 を对象に，一方の円盤が相対的に回転運動する平行円盤 間微小間隙のせん断流れモードにおらけるそのER特性を その可視化した流動挙動との密接な関連のもとに検討し ている。

\section{2. レオロジー計測と流䌾場の可視化}

供試ER流体として，二酸化チタン TiO2（平均粒子径 $15 \mathrm{~nm})$ を $30[\mathrm{cSt}]$ のシリコーン油中に35[wt\%]で分散した ナノ粒子ER流体（MT-150A）を用いた。

Fig. 1に電場印加型高精度レオメータを用いた E R 流
体のレオロジー計測と流動場の可視化法の概略図を示寸 電場印加が可能な直径 $d=\phi 20 \mathrm{~mm}$ の平行円盤型レオメー 夕 [HAAKE, RheoStress RS150］を用いて，回転せん断流 れ場における誘起せん断応力 $\tau=16 M / \pi d^{3}, M:$ トルク)の 時間的な变化特性の测定を $1000 \mathrm{~s}$ 間行った. 下側円盤(直 径 $38 \mathrm{~mm}$ )は装圆下部から流動構造を観察するためITO膜 付きガラス電極としている，電極間距離hは微小間隙に おけすレオロジー特性を調べるため0.05, $0.07,0.1 ， 0.2$ $0.3,0.4$ 及び $0.5 \mathrm{~mm}$ と変化させ, 印加電場強度 $E$ は 0.5 , $1.0 ， 1.5,2.0,3.0,4.0$, 及び5.0 kV/mmと変化させる. 円盤外周部で定義したせん断速度は $100 \mathrm{~s}^{-1}$ 一定とする. 円盤間のER 流体が形成する流動パターンの変化を下側 のガラス円盤電極の下方からハロゲン光を照射しミラー を介してCCDカメラで撽影し，PCにディジタル記録し

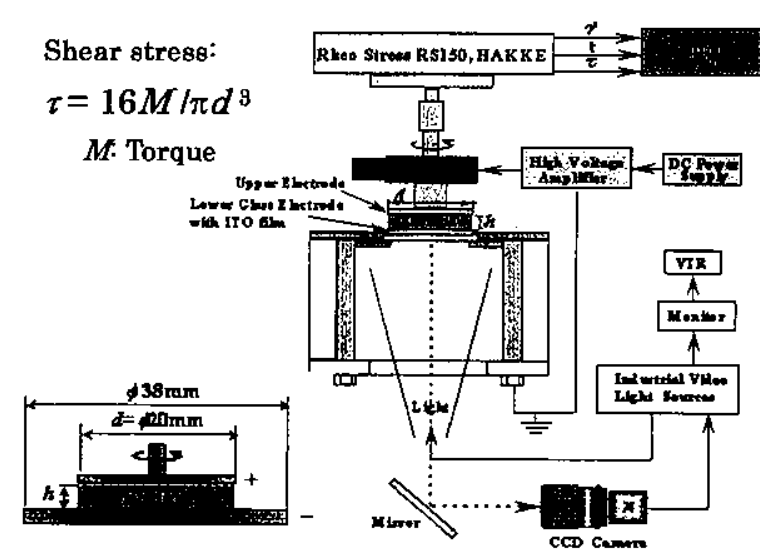

Fig.1 Rheological measurement and flow visualization using a rotary parallel disk rheometer. 
て流動特性の時間的な変化について検討している。また， レオメータで測定後 $\mathrm{ER}$ 流体を採取し, 光学顕微鏡を用 いて無電場下での粒子の分散状態の観察も行った.

\section{ER効果及び流動場の計測轺果と考察}

Fig 2にはMT-150Aのせん断流れ $\left(h=0.1 \mathrm{~mm}, \dot{\gamma}=100 \mathrm{~s}^{-1}\right)$ におうけるDC及びAC電場強度 $E=2.0 \mathrm{kV} / \mathrm{mm}$ 印加時の誘起 せん断応力の電極間隙 $h$ とせん断時間 $t$ による変化を，

Fig 3にはその際の対応寸る流動挙動の変化を示す. DC電 場印加時には，電極間隙が狭い $h=0.05,0.07 \mathrm{~mm}$ では凝集 塊が， $h=0.1 \mathrm{~mm}$ では層状の円環構造が観察でき，せん 断応力の值には電極間隙及びせん断時閒によってバラつ きが見られる。さらに電極間吵が広くなると，この円環 が徐々に太くなり，電極間隙が $0.3 \mathrm{~mm}$ の時には円環が 僅かに観察されるがほぼ消え，せん断応力は著しく低い 值を示す．電極間隙 $h=0.4,0.5 \mathrm{~mm}$ では流動挙動には大き な変化が観察されず一様となり，せん断時間に対するせ ん断応力の変動もほぼ見られなくなる，また，せん断応 力は電極間隙が大きくなるにつれて徐々に上昇する。一 方， $\mathrm{AC}$ 電場印加時 $(1 \mathrm{kHz})$ には，DC電場印加時のものと 比較すると，誘起せん断応力は低い值を示すが，比較的 狭い電極閒隙でも時間的な変動はなく安定しており，電 極間隙が大きくなるほどせん断応力も比例的に上昇する
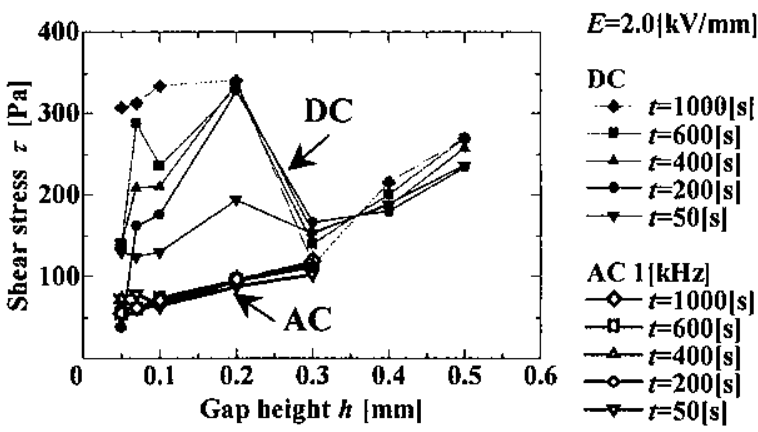

Fig 2 Changes of shear stress of nano-particle ER fluid with electrode gap in terms of shearing time under $\mathrm{DC}$ or $\mathrm{AC}$ electric field $(E=2.0 \mathrm{kV} / \mathrm{mm})$.
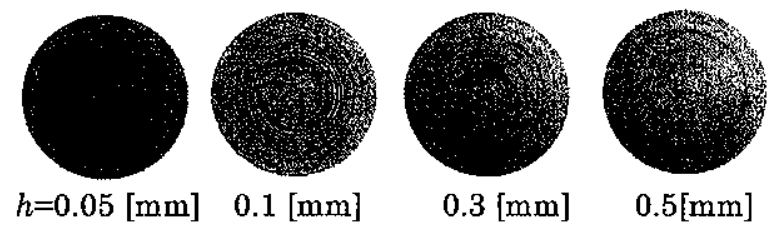

$0.1[\mathrm{~mm}]$

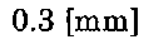

$0.5[\mathrm{~mm}]$

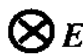

(a) DC electric field
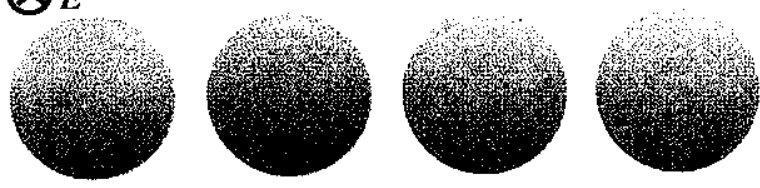

$h=0.05[\mathrm{~mm}]$

$0.1[\mathrm{~mm}]$

$0.2[\mathrm{~mm}]$

$0.3[\mathrm{~mm}]$

(b) AC electric field $(f=1 \mathrm{kHz})$

Fig 3 Changes of ER fluid shear flow patterns with gap $h$ for MT-150A ( $t=600 \mathrm{sec}, E=2.0 \mathrm{kV} / \mathrm{mm})$.
ことが分かる。また，Fig 3(b)で観察されるように， AC 電場印加時 $(1[\mathrm{kHz}])$ には流動挙動には電場強度や電極間 隙に対して有意な変化は観察されなかった。

Fig 4には，ナノ粒子ER 流体にDC電場印加したもの [Fig 4(a)]とDC電場印加した後に続けてAC電場印加した もの[Fig 4(b)]をそれぞれ採取し，光学顕微鏡で粒子の分 散状態を観察した結果を示す。 DC電場印加したもので

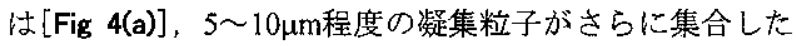
より大きな二次粒子群を形成しているのに対して，さら にAC電場を印加した場合には[Fig 4(b)]，DC印加時に観 察された大きな二次粒子群が分解され，2 $5 \mu \mathrm{m}$ 程度の比 較的小さな粒子が均一に分散されている。このことによ $\eta, \mathrm{DC}$ 電場下では $h=0.3 \mathrm{~mm}$ 以下の微小間隙では時間的 に不安定な值をとるのに対して，AC電場印加時には, 微 小間隙でも時間的に安定したせん断応力を示しているも のと考㝋られる

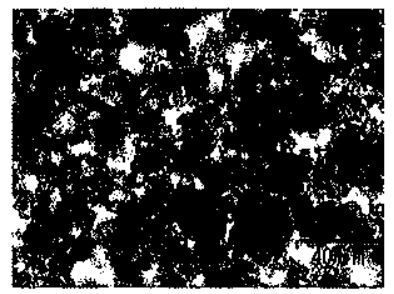

(a) DC

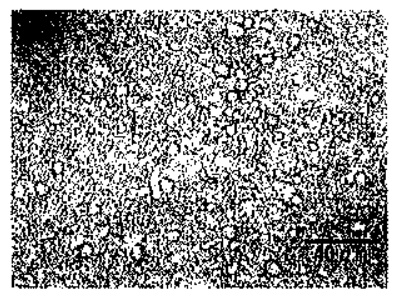

(b) $\mathrm{AC}$
Fig 4 Micrograph of particles in ER fluid after applied electric field.

\section{4. 結 言}

TiO2のナノ粒子ER流体は，DC電場下ではナノ粒子 が凝集したミクロンサイズの二次粒子がさらに集合した 数十ミクロンの粒子群を形成し, 微小電極間隙では, マ イクロ粒子分散 E R流体と同様に，多層円環状パターン や凝集塊を形成しせん断応力に大きな乱れが生じ不安定 な値を示す，一方， $\mathrm{AC}(1 \mathrm{kHz})$ 電場では，DC印加時に観 察された数十ミクロンの粒子群が分解され，ナノ粒子か らなる数ミクロンの二次粒子が均一に分散されるため, DC電場と比較してせん断㐫力のレベルは低下するが, 微 小電極間腺でも時間的に非常に安定した值を示した。そ の流動举動にも電場強度や電極間隙の変化に対する有意 なパターン形成は認められなかった。

\section{参考文 献}

1）中野政身：ER／MR流体のレオロジー及び流動特性, 可視化情報, Vol.27, No.105 (2007) pp.19-26.

2) M. Nakano, et al.: Dynamic shear flow of electrorheological fluids between two rotating parallel disks, CD-ROM Proc. of the Sixth JFPS Int. Symp. on Fluid Power, Paper No.2D4-5(2005), 612-617.

3）中野政身：ナノ・マイク口粒子分散系 ER流体のマイク ロギヤップフローとその点字表示システムへの応用, 混 相流, Vol23, No.2 (2009) pp.135-142. 